Société d'histoire de la révolution de 1848 et des

révolutions du XIXe siècle

$19 \mid 1999$

Aspects de la production culturelle au XIXe siècle

\title{
Publications disponibles à la vente
}

\section{OpenEdition \\ Journals}

Édition électronique

URL : http://journals.openedition.org/rh19/203

DOI : $10.4000 /$ rh 19.203

ISSN : $1777-5329$

\section{Éditeur}

La Société de 1848

\section{Édition imprimée}

Date de publication : 1 décembre 1999

Pagination : 192-193

ISSN : 1265-1354

Référence électronique

"Publications disponibles à la vente », Revue d'histoire du XIXe siècle [En ligne], 19| 1999, mis en ligne le 26 août 2008, consulté le 15 septembre 2020. URL : http://journals.openedition.org/rh19/203

Ce document a été généré automatiquement le 15 septembre 2020

Tous droits réservés 


\section{Publications disponibles à la vente}

Notre société a décidé de mettre en vente les exemplaires disponibles de ses anciennes publications. Pour chaque série, il ne nous reste souvent que quelques exemplaires : les demandes seront donc traitées par ordre d'arrivée.

Nous prions nos adhérents de nous excuser de ne pas détailler le contenu de chaque numéro. Nous conseillons la consultation des Tables des publications de la Société rédigées par Lise Dubief et publiées en 1957.

- Du Bulletin paru de 1904 à 1940, sont disponibles :

- Les numéros 61 (mars-avril 1914), 62 (mai-juin 1914), 63 (juillet-août 1915), 64 (sept.oct. 1915), 65 (nov.-déc. 1915), 66 (janv.-fév. 1916), 67 (mars-avril 1916), 68 (mai-juin 1916), 69 (août-sept. 1916), 70 (nov.-déc. 1916-janv. 1917), 71 (fév.-mars-avril 1917), 72 (mai-juin-juillet 1917), 73 (sept.-oct.-nov. 1917), 74 (déc. 1917-janv.-fév. 1918), 75 (marsavril-mai 1918), 76 (juin-juillet-août 1918), 77 (sept.-oct.-nov. 1918), 78 (déc. 1918-janv.fév. 1919), 79 (mars-avril-mai 1919).

- Les numéros 145 (juin-juillet-août 1933), 151 (déc. 1934-janv.-fév. 1935), 152 (marsavril-mai 1935), 153 (juin-juillet-août 1935), 154 (sept.-oct.-nov. 1935) 155 (déc. 1935janv.-fév. 1936), 157 (juin-juillet-août 1936), 158 (sept.-oct.-nov. 1936), 160 (mars-avrilmai 1937), 162 (sept.-oct.-nov. 1937), 169 (juin-juillet-août 1939), 171 (déc. 1939-janv.fév. 1940).

Prix de vente : $30 \mathrm{~F}$ le numéro + port.

- Du Bulletin paru de 1946 à 1952, sont disponibles :

- Les numéros 172 (automne 1946), 177 (été 1947), 181 (nov. 1948), 186 (juillet 1950), 188 (mai 1951), 189 (décembre 1951).

Prix de vente : $50 \mathrm{~F}$ le numéro + port.

- De la bibliothèque de la Révolution de 1848, sont disponibles:

- Le tome VII : La propagande bonapartiste en 1848, par R. Pimienta, 1911.

Prix de vente : $75 \mathrm{~F}$ le numéro + port.

- Le tome XVI : Études de A. Armengaud, M. Dommanget, J. Droz, H. Dubief, J. Gaillard, J. Godechot, A. Hamelin, J. Vidalenc, 1954.

Prix de vente : $50 \mathrm{~F}$ le numéro + port.

- Le tome XX : Le Choléra, la première épidémie du XIX ${ }^{e}$ siècle, sous la direction de Louis Chevalier, 1958.

Prix de vente : $50 \mathrm{~F}$ le numéro + port. 
- Le tome XXII : Réaction et Suffrage universel en France et en Allemagne, sous la direction de Jacques Droz, 1963.

Prix de vent : $50 \mathrm{~F}+$ port.

- Le tome XXIII : La presse ouvrière (1819-1850), sous la direction de Jacques Godechot, 1966.

Prix de vente : $75 \mathrm{~F}$ le numéro + port.

- Le tome XXIV : Les Ouvriers de Paris. L'organisation (1848-1851), par Rémy Gossez, 1967.

Prix de vente : $75 \mathrm{~F}$ le numéro + port.

Les commandes doivent être adressées à :

Pierre Lenoël - 1 square de Verdun - 75010 Paris.

Attention : Ne payez pas à la commande. Attendez de recevoir la facture qui prendra en compte les frais de port. Merci. 